\title{
WHALE WATCHER CHARACTERISTICS, EXPECTATION- SATISFACTION, AND OPINIONS ABOUT WHALE WATCHING FOR PRIVATE VS COMMUNITY-BASED COMPANIES IN BAHÍA DE BANDERAS, MEXICO
}

\author{
J.L. CORNEJO-ORTEGA ${ }^{1}$, R.M. CHAVEZ-DAGOSTINO ${ }^{1} \&$ C.D. MALCOLM ${ }^{2}$ \\ ${ }^{1}$ Universidad de Guadalajara, México. \\ ${ }^{2}$ Brandon University, Canada.
}

\begin{abstract}
Whale watching has become a globally important ecotourism activity due to its economic and conservation potential. The predictable presence of humpback whales (Megaptera novaeangliae) and consequent popularity of whale watching in Bahía de Banderas, near Puerto Vallarta on the Pacific coast of Mexico, throughout the winter months has resulted in a successful private and community-based whale-watching industry in. While private whale watching companies are operated as commercial, larger scale businesses, community-based whale watching operates with less financial resources and experience in tourism affairs. How do these two different approaches meet the needs of tourists and contribute to conservation? This paper compares whale watching tourists' satisfaction between private and community-based platforms. During 2013-2014, a questionnaire survey was administered to whale watching tourists aboard private $(n=246)$ and community-based vessels $(n=101)$ using the intercept method. Whale watchers from both types of companies reported high satisfaction in environmental education. There appeared to be a different demand for the two types of companies, as a greater proportion of Mexican nationals and those who had been whale watching previously chose to go whale watching on community-based vessels.
\end{abstract}

Keywords: Ecotourism, private and community-based companies, satisfaction

\section{INTRODUCTION}

In Mexico, ecotourism has been used as a strategy for conservation and poverty reduction [1], and various governmental and non-governmental organizations (NGOs) have supported the development of ecotourism projects, including in rural, organized communities [2,3]. Ecotourism products have primarily been offered through a private, commercial industry, and frequently used as a marketing strategy to attract a new and growing set of tourists who possess environmental awareness, and are willing to travel to new, untapped destinations [4]. These types of companies, with greater financial capacity, may have some advantages over community-based operations, such as cooperatives, to achieve the goals of ecotourism and be sustainable in the long term.

The term community-based tourism (CBT), used frequently in the 1990s [5], was centered initially on studying the economic benefits [6]. Currently, at least in theoretical discourse, CBT is associated with social justice and the desire to ensure a more equitable distribution of economic and social benefits of tourism, as well as democratic mechanisms for collective community participation (e.g. consensus decision-making) [5]. For this to occur, ecotourism activities should be based on a political, ideological and ethical meaning of sustainable development, with social and environmental objectives that can produce more equitable economic returns that lead to empowerment of, and decision-making by, local community groups $[3,7,8]$.

Whale watching is often considered an ecotourism activity, as it holds the potential for practices that are sustainable, ecologically sound, educational, and profitable [9]. However, 
there is also concern that whale watching can be detrimental to the target species. Numerous studies have shown that cetaceans exhibit behavioral changes in response to whale-watching boat traffic, including restriction of biologically important behaviors such as feeding and resting, reproductive rates or direct mortality $[10,11]$.

Globally, commercial whale watching is an important component of marine-oriented tourism that generated 2.1 billion USD and attracted more than 13 million of tourists in 2008, the most recent global compendium of whale watching statistics [12]. Cisneros-Montemayor et al. [13] suggest that the potential revenue for the global whale watching industry could be over 2.5 billion USD in yearly revenue and provide approximately 19,000 jobs.

As the number of global whale watchers has increased, so too has the opportunity to sensitize tourists towards marine conservation issues. Whale watching tourists have been shown to have a high concern for marine mammal conservation in general [14], but conservation awareness can be increased through education and interpretation onboard whale watching vessels. As operations in developing countries has increased considerably in the past decade, practices are unregulated, without supervision by the authorities and not informed by research, especially research into the human dimensions of the tourist experience that is closely related to the encounter management and the number of boats involved in the experience [15]. The quality of the experience of mammal watchers has been gauged using aspects like safety, educational value, perception of the boat driver's behavior, and overall satisfaction [16]. Whale watching tourists in Scotland were found to be more environmental aware than general tourists and choose operators with proven good practices [17]. In Dominican Republic, surveys indicated that tourists generally favoured sustainable practices and prefer tour operators to partake in biological conservation [14].

Whale watching in general has become an increasingly responsible activity aimed at protecting whales during viewing activities, although monitoring is continually necessary [17]. In some cases there is also required training for interpretation and education, monitoring and human dimensions inquiry to inform the development of interpretation programs on board whale watching vessels.

The study reported in this paper addresses this human dimensions issue, in which we investigate the expectations and satisfactions of tourists choosing a private (commercial companies operating out Puerto Vallarta) or the cooperative community based company, out of Punta de Mita at El Anclote, with the aim of contributing to the understanding of whale watching tourists in Bahía de Banderas and informing environmental education and awareness in the area.

The predictable presence of humpback whales (Megaptera novaeangliae) throughout the winter months in Bahía de Banderas, on the Pacific Coast of Mexico, has resulted in a successful whale watching industry, mainly out of Puerto Vallarta.

The aim of this study is to compare tourist characteristics, expectation-satisfaction, and opinions about whale watching between whale watchers that choose private versus communitybased companies offering whale watching in Bahía de Banderas.

\subsection{Whale watching in Bahía de Banderas}

Bahía de Banderas is located in the Eastern Pacific zoogeographic region [18], within the Mexican Province, which includes the mouth of the Gulf of California [19] (Fig. 1). The region's biotic and abiotic characteristics are influenced by the northern and southern ends of two main water masses and currents: the California Current and the subtropical water reflux 
of the Gulf of California to the north, and water masses from tropical systems brought north by the North Equatorial Current [18]. Humpback whales from the north Pacific feeding grounds in the Gulf of Alaska seek the warm and shallow waters of Bahía de Banderas during the mating and breeding season between November and April each year [20].

Whale watching in Bahía de Banderas is an important economic component of the regional tourism industry. The local whale watching industry grew throughout the first decade of the 2000 's, beginning with approximately 14,000 tourists in $2001-2002$, rising to 38,000 in 2006-2007, and to 76,000 in 2008-2009 [21]. Growth in the local whale watching industry and tourist participation is reflected in the number of vessel permits issued to operators, which grew from 44 in 2005 to 183 in 2014 [22]. Whale watching is currently offered by approximately 15 companies in and around Puerto Vallarta that provide 450 direct seasonal jobs annually [23]. The majority of the operators are small, private commercial companies, using vessels with capacities up to 10 people (e.g. small zodiac-type and single-hulled vessels, locally called pangas), along with several other vessels with capacities up to 200 passengers, that can serve approximately 12,000 tourists per season. In addition, there is a rural cooperative organization, the Sociedad Cooperativa Corral del Risco (herein after referred to as the Cooperativa), which operates in Punta de Mita at the north end of the bay (Fig. 1). The Cooperativa is composed of approximately 23 pangas, as well as 20 other pangas not associated with the cooperative that have permits for whale watching. The private commercial companies are usually staffed with guides possessing a biological education that are available to interpret the whale watching experience for tourists, while on the community-based vessels tourists are often accompanied only by the owner/driver of the boat In total, there were 125 whale-watching vessel permits for the bay issued in 2014 by SEMARNAT [23]. The Cooperativa was established in (1989 put in year) by a group of anglers displaced by a tourist hotel development in nearby Corral del Risco; they primarily offer whale watching, although they will also take tourists diving, snorkeling, and surfing throughout northern Bahía de Banderas, as well as tours to the Islas Marietas, a marine ecological reserve (Fig. 1).

Commercial whale watching in the Bahía de Banderas has been studied from various viewpoints. Rodriguez-Vazquez [24] analyzed the tourism potential of whale watching, realizing the growing interest in this segment, as well as the opportunity to deliver marine environmental education, especially about marine mammals. Beets [25] described the activity in the bay as sustainable but noted some issues associated with business practices and compliance with standards. Although it is considered a low-impact activity, CornejoOrtega, Chávez-Dagostino and Massam [26], calculated the ecological as well as carbon footprints of whale watching in the bay and, revealed that although the impacts were primarily local, the global implications of the activity should be considered as well [27]. Human dimensions research has also been undertaken. Avila-Foucat, Sánchez-Vargas, Frish-Jordan, et al. [28] observed that vessels crowded around whales negatively affects the probability that tourists will return to whale watching again in the area, while at the same time reporting a positive impact on attitude towards conservation. Cornejo-Ortega, ChávezDagostino and Ivanova-Boncheva [29] also examined the perceptions of tourists with respect to whale watching and climate change. Finally, Malcolm, Chávez-Dagostino and Cornejo-Ortega [30] compared expectations of whale watching guides versus whale watching tourists. They found that guides placed a higher importance on learning, while tourists were more interested in experiential thrills such as viewing whales up close and seeing behaviours such as breaching. 
There are also NGO initiatives in the region, such as Ecología y Conservación de Ballenas (ECOBAC, www.ecobac.org), which provides education and conducts photo-identification to contribute to research, protection, and conservation of natural resources, particularly humpback whales.

\section{METHODS}

Using the intercept method, we administered a questionnaire survey to whale watching tourists aboard private (PC) and community-based (CC) vessels during the 2013 and 2014 whale watching seasons. The questionnaire was available in either English or Spanish and collected data at two time points: before and following the trip. Following check-in, but before boarding the vessel, respondents answered questions regarding previous experience viewing whales, expectations, opinions about whale-watching management, and demographics, Satisfaction questions were answered following the trip, as the vessel was travelling through the harbor to the dock (Fig. 1).

The size for a simple random sample was calculated as in Fig. 2 [31]. Questionnaires were piloted and revised according to feedback from pilot respondents. Quantitative data were analyzed with SPSS. We first compared demographics and previous experience with whales and whale watching between PC $(n=246)$ and CC $(n=101)$ whale-watchers. This was followed by comparison of expectation (importance) and satisfaction of fourteen experiencial items on four-point Likert scales from 1 (Not at all important, Not at all satisfied) to 4 (Essential,

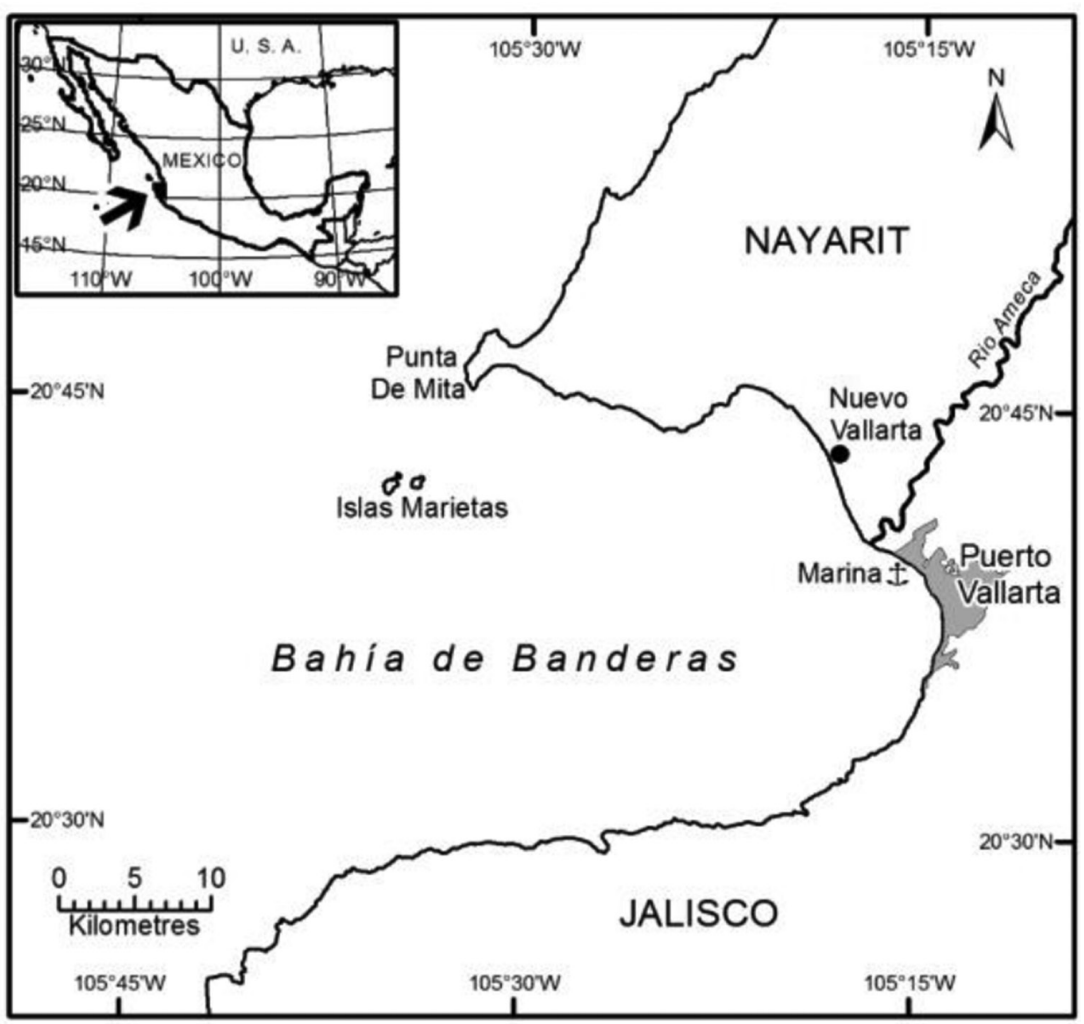

Figure 1. Puerto Vallarta and Punta de Mita locations at Bahía de Banderas 


$$
\begin{aligned}
& n=\frac{Z^{2} P Q N}{N E^{2}+Z^{2} P Q} \approx 322 \\
& n=\text { Sise for a simple random sample } \\
& Z=1.96 \text { Trust, normal value in the normal curve abssisa } \\
& \varepsilon= \pm 5 \% \text { Absolute maximum statistica lerror. } \\
& P=70 \%, Q=30 \% . \\
& N=78,000 \text { Tourists }
\end{aligned}
$$

Figure 2. Sampling technique

Very satisfied). We then used the same method to test for differences in opinions between the two groups towards eight statements regarding whale and whale-watching management.

\section{RESULTS}

\subsection{Demographics}

The PC whale-watcher sample was more diversified in origin that the $\mathrm{CC}$ whale-watchers (Table 1); this difference was statistically significant $(\mathrm{U}=8987.5, \mathrm{p}<0.000)$. PC respondents came from eight different countries, primarily the United States (55.1\%), Mexico and Canada, while the majority of CC whale-watchers were Mexican (80.8\%).

Other demographic metrics were different between the PC and $\mathrm{CC}$ groups as well: gender, age and with whom the respondent traveled on the trip were significantly different between groups. Level of education was not. Forty-percent of PC respondents were male, compared to $56.6 \%$ for $\mathrm{CC}$ whale-watchers $(\mathrm{U}=9705.5, \mathrm{p}=0.006)$; the majority of $\mathrm{PC}$ respondents were over 50 years in age $(58.1 \%)$, while the majority of $\mathrm{CC}$ respondents were younger, 20 to 39 years of age $(74 \%) \quad \mathrm{U}=5483.5, \mathrm{p}<0.000)$. The majority of PC whale watchers $(63.4 \%)$ made the trip with a spouse or partner, while only $41.2 \%$ of CC participants did so (U=9535.5, $\mathrm{p}=0.009$ ). Education levels were similar between groups, with $68.4 \%$ of PC and $62.1 \%$ of CC respondents reported completing an undergraduate or higher degree.

\subsection{Previous experience whale-watching and learning about whales}

The majority of respondents on PC vessels had never been on a commercial whale-watching trip prior to the trip on which they filled out the questionnaire (Table 2), compared to $40 \%$ of $\mathrm{CC}$ whale-watchers, the majority of whom had been on a commercial whale-watching trip

Table 1. Whale watching visitor's origin country for PC and CC in the Bahía de Banderas

\begin{tabular}{llllllllr}
\hline & USA & Netherlands & Mexico & Canada & Spain & Peru & \multicolumn{2}{c}{ Costa Rica Israel } \\
\hline PC & $55.1 \%$ & $2.1 \%$ & $20.3 \%$ & $19.1 \%$ & $0.8 \%$ & $0.9 \%$ & $0.9 \%$ & $0.8 \%$ \\
CC & $16.2 \%$ & & $80.8 \%$ & $3.0 \%$ & & & & \\
\hline
\end{tabular}


Table 2. Number of times respondents had previously been on a commercial whale-watching trip

\begin{tabular}{lllllll}
\hline & Never & Once & 2-5 Times & 610 Times & More than 10 times & Total \\
\hline PC & $61.9 \%$ & $18.4 \%$ & $13.9 \%$ & $3.7 \%$ & $2.0 \%$ & $100.0 \%$ \\
CC & $39.6 \%$ & $27.7 \%$ & $28.7 \%$ & $1.0 \%$ & $3.0 \%$ & $100.0 \%$ \\
\hline
\end{tabular}

between one to five times ( $U=9630, \mathrm{p}<0.000)$. Most PC whale watchers have never made this kind of trip. However, of those who had been whale watcher before, $25.9 \%$ of PC and $14.1 \%$ of CC respondents, respectively, had gone whale watching in countries other than Mexico. For $62.9 \%$ of the PC respondents whale watching was one of several activities during their visit, compared to only $38.5 \%$ of $\mathrm{CC}$ tourists $(\mathrm{U}=9630, \mathrm{p}<0.000)$, who had mainly come to the area to go whale watching.

Whale watchers from both groups reported similar use of media sources to learn about whales prior to their whale watching trip (Table 3). Television remains the preferred medium to learn about these trips.

\subsection{Expectation - Satisfaction}

It was important for both groups to experience a whale watching trip while in the Bahía de Banderas area, although slightly more so for the PC respondents, $79.8 \%$ of whom indicated it was important or essential, compared to $71.3 \%$ for $\mathrm{CC}$ whale-watchers.

Table 4 presents mean scores for the fourteen importance items for each group type. The scores indicate that the items primarily range between "slightly important" to "important" and there are no statistically significant differences between the groups (at $p \geq 0.05$ ) except for the item "How important is to identify different species of whales?" which is less important for the PC respondents.

Table 5 presents mean scores for fourteen satisfaction items for each group type. The scores are statistically significant between both companies $(\mathrm{p} \leq 0.05)$ except for the items "See a variety of wildlife besides whales" and "Learn about whales in local culture." In each case, the PC group indicated a higher satisfaction.

Fig. 3 reveals that the $\mathrm{PC}$ group reported greater satisfaction than expectation (importance) for all items, which is demonstrated in the Fig. 4 by all X's below the isoline. In contrast, the $\mathrm{CC}$ whale-watchers reported lower satisfaction than importance scores for seven of the 14 items, indicated by the O's above the isoline ("See lots of whales," "See whales in a manner which is respectful to the whales and their environment," "See spectacular behaviours such

Table 3. Media used by visitors to learn about whales

\begin{tabular}{lllllll}
\hline Books & Magazines & Internet & Educational Videos & Television & Aquariums & Museums \\
\hline PC $38.5 \%$ & $63.8 \%$ & $51.6 \%$ & $24.8 \%$ & $75.6 \%$ & $50.8 \%$ & $19.5 \%$ \\
CC $28.7 \%$ & $66.3 \%$ & $66.3 \%$ & $30.7 \%$ & $57.4 \%$ & $20.8 \%$ & $7.9 \%$ \\
\hline
\end{tabular}


Table 4. Calculation of importance index by group type

\begin{tabular}{|c|c|c|c|c|}
\hline \multirow[b]{2}{*}{$\begin{array}{l}\text { Expectation item - How impor- } \\
\text { tant are the following items for } \\
\text { your whale-watching tip today? }\end{array}$} & \multicolumn{3}{|c|}{ Mean score ${ }^{1}$} & \multirow[b]{2}{*}{$\begin{array}{l}\text { Chi-square } \\
\left(X^{2}\right)\end{array}$} \\
\hline & $\begin{array}{l}\text { Private } \\
\text { company } \\
(\text { PC) }\end{array}$ & $\begin{array}{l}\text { Community } \\
\text { cooperative } \\
\text { (CC) }\end{array}$ & $\begin{array}{l}\text { Groups } \\
\text { combined }\end{array}$ & \\
\hline $\begin{array}{l}\text { See whales in a manner which is } \\
\text { respectful to the whales and their } \\
\text { environment }\end{array}$ & 3.5 & 3.3 & 3.44 & $\begin{array}{l}7.325 \\
\mathrm{P}=0.062\end{array}$ \\
\hline See a whale even if it is only one & 3.35 & 3.19 & 3.3 & $\begin{array}{l}7.782 \\
\mathrm{P}=0.051\end{array}$ \\
\hline Learn about protection of whales & 2.96 & 3.08 & 2.99 & $\begin{array}{l}6.334 \\
P=0.096\end{array}$ \\
\hline See whales up close to the boat & 3.01 & 2.91 & 2.98 & $\begin{array}{l}3.316 \\
P=0.345\end{array}$ \\
\hline Learn about ocean conservation & 2.94 & 3.06 & 2.98 & $\begin{array}{l}2.566 \\
P=0.463\end{array}$ \\
\hline $\begin{array}{l}\text { See spectacular behaviours such } \\
\text { as jumping or a whale's tail as it } \\
\text { dives }\end{array}$ & 2.95 & 2.98 & 2.96 & $\begin{array}{l}7.700 \\
P=0.053\end{array}$ \\
\hline $\begin{array}{l}\text { Learn about whale behaviours } \\
\text { (jumping, socializing, migration) }\end{array}$ & 2.94 & 3 & 2.96 & $\begin{array}{l}1.981 \\
\mathrm{P}=0.576\end{array}$ \\
\hline Take pictures of the whales & 2.91 & 3.04 & 2.95 & $\begin{array}{l}6.663 \\
\mathrm{P}=0.083\end{array}$ \\
\hline See lots of whales & 2.94 & 2.93 & 2.93 & $\begin{array}{l}4.344 \\
P=0.227\end{array}$ \\
\hline $\begin{array}{l}\text { Learn about regulations for watch- } \\
\text { ing whales }\end{array}$ & 2.86 & 2.95 & 2.89 & $\begin{array}{l}7.287 \\
\mathrm{P}=0.063\end{array}$ \\
\hline $\begin{array}{l}\text { Learn about whale biology (feed- } \\
\text { ing, reproduction) }\end{array}$ & 2.81 & 2.92 & 2.84 & $\begin{array}{l}6.175 \\
P=0.103\end{array}$ \\
\hline $\begin{array}{l}\text { Learn about whales in local } \\
\text { culture }\end{array}$ & 2.81 & 2.86 & 2.83 & $\begin{array}{l}1.615 \\
P=0.656\end{array}$ \\
\hline $\begin{array}{l}\text { Learn how to identify different } \\
\text { species of whales }\end{array}$ & 2.76 & 2.95 & 2.82 & $\begin{array}{l}10.581 \\
P=0.014\end{array}$ \\
\hline $\begin{array}{l}\text { See a variety of wildlife besides } \\
\text { whales }\end{array}$ & 2.62 & 2.86 & 2.7 & $\begin{array}{l}7.724 \\
P=0.052\end{array}$ \\
\hline
\end{tabular}

${ }^{1}$ Likert index: 1: not at all important, 2: slightly important, 3: important, 4: essential

as jumping or a whale's tail as it dives," "Learn about protection of whales," "Learn about whale behaviours (jumping, socializing, migration)," "Learn about ocean conservation," and "Learn how to identify different species of whales." Although four of these seven items possess a mean score of 3.0 ("satisfied") or higher, the results indicate levels of satisfaction that do not meet the respondents' expectations for these items. 
Table 5. Calculation of satisfaction index by company

\begin{tabular}{|c|c|c|c|c|}
\hline & Mean scor & & & $\begin{array}{l}\text { Chi-square } \\
\left(X^{2}\right)\end{array}$ \\
\hline Dependent variables & $\begin{array}{l}\text { Private } \\
\text { company }\end{array}$ & $\begin{array}{l}\text { Community } \\
\text { company }\end{array}$ & $\begin{array}{l}\text { Locations } \\
\text { combined }\end{array}$ & PC vs CC \\
\hline $\begin{array}{l}\text { See whales in a manner which is } \\
\text { respectful to the whales and their } \\
\text { environment }\end{array}$ & 3.66 & 3.24 & 3.55 & $\begin{array}{l}32.974 \\
P<0.000\end{array}$ \\
\hline See a whale & 3.66 & 3.22 & 3.54 & $\begin{array}{l}34.608 \\
P<0.000\end{array}$ \\
\hline $\begin{array}{l}\text { Learn about whale biology (feed- } \\
\text { ing, reproduction) }\end{array}$ & 3.6 & 2.99 & 3.44 & $\begin{array}{l}42.993 \\
P<0.000\end{array}$ \\
\hline $\begin{array}{l}\text { Learn about whale behaviours } \\
\text { (jumping, socializing, migration) }\end{array}$ & 3.55 & 2.92 & 3.38 & $\begin{array}{l}43.473 \\
P<0.000\end{array}$ \\
\hline See lots of whales & 3.5 & 2.92 & 3.34 & $\begin{array}{l}35.902 \\
P<0.000\end{array}$ \\
\hline See whales up close to the boat & 3.4 & 3.1 & 3.32 & $\begin{array}{l}16.994 \\
P=0.001\end{array}$ \\
\hline $\begin{array}{l}\text { See spectacular behaviours such } \\
\text { as jumping or a whale's tail as it } \\
\text { dives }\end{array}$ & 3.45 & 2.9 & 3.3 & $\begin{array}{l}29.247 \\
P<0.000\end{array}$ \\
\hline Take pictures of whales & 3.33 & 3.19 & 3.29 & $\begin{array}{l}9.570 \\
P=0.023\end{array}$ \\
\hline Learn about protection of whales & 3.3 & 3.01 & 3.22 & $\begin{array}{l}16.585 \\
P=0.001\end{array}$ \\
\hline $\begin{array}{l}\text { See a variety of wildlife besides } \\
\text { whales }\end{array}$ & 3.13 & 3.05 & 3.1 & $\begin{array}{l}3.277 \\
\mathrm{P}=0.351\end{array}$ \\
\hline $\begin{array}{l}\text { Learn about regulations for } \\
\text { watching whales }\end{array}$ & 3.12 & 2.95 & 3.08 & $\begin{array}{l}8.870 \\
P=0.031\end{array}$ \\
\hline $\begin{array}{l}\text { Learn how to identify different } \\
\text { species of whales }\end{array}$ & 3.16 & 2.88 & 3.08 & $\begin{array}{l}11.441 \\
P=0.010\end{array}$ \\
\hline Learn about ocean conservation & 3.05 & 2.95 & 3.02 & $\begin{array}{l}10.586 \\
P=0.014\end{array}$ \\
\hline $\begin{array}{l}\text { Learn about whales in local } \\
\text { culture }\end{array}$ & 3.05 & 2.96 & 3.02 & $\begin{array}{l}4.075 \\
P=0.253\end{array}$ \\
\hline
\end{tabular}

3.4 Whales and whale-watching management

The majority of both PC (66.5\%) and CC (61.4\%) whale watchers agree or strongly agree that "Paying for a whale watching trip should guarantee I see whales." Most visitors responded that "The number of whale watching boats around the whales should be limited," (88.9\% and $79.0 \%$ respectively). Respondents from both groups ( $\mathrm{PC}=78.4 \%, \mathrm{CC}=78.8 \%$ ) agreed or strongly agreed that "There should be some areas set aside where whale watching is not permitted. 


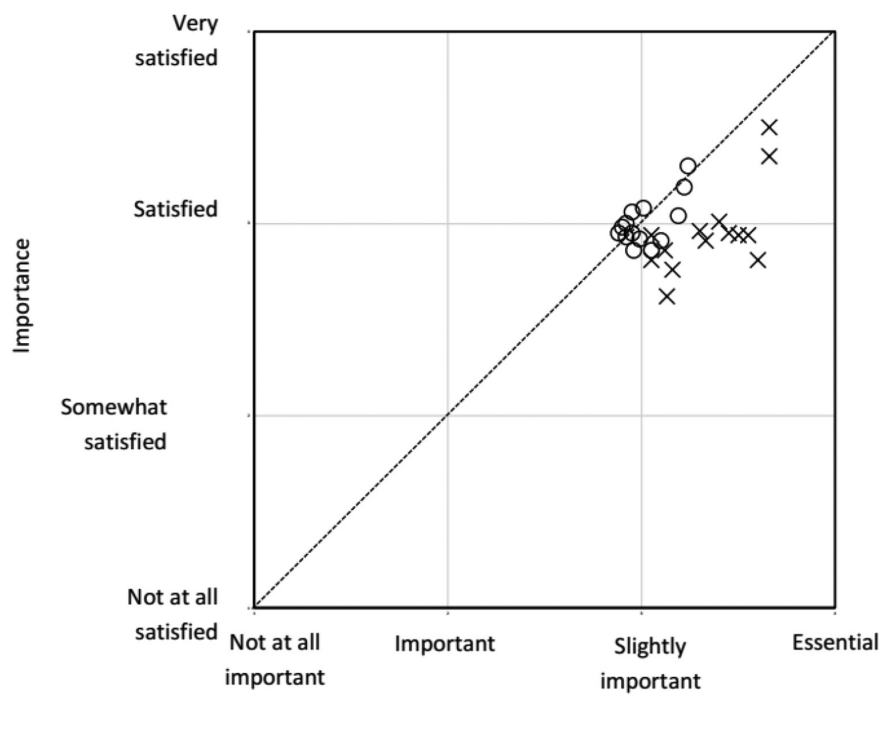

Satisfaction

Figure 3. Satisfaction versus expectation (importance) for private company $(\mathrm{PC}=\mathrm{X})$ versus community cooperative $(\mathrm{CC}=\mathrm{O})$ whale-watching groups.

Visitors from both groups also agreed that "Whale populations that are endangered, they should be off limits to whale-watching boats $(\mathrm{PC}=246, \mathrm{CC}=101)$. With respect to whether" $\mathrm{A}$ portion of the costs to go whale watching should go directly to whale research and management," $90.6 \%$ of PC whale watchers agreed or strongly agreed, compared to $78.0 \%$ of CC whale watchers, which is significantly different.. The two groups were again similar in their responses to whether "It is acceptable to keep whales in aquariums; $74.2 \%$ of PC respondents and $64.0 \%$ of CC disagreed or strongly disagreed (Table 6).

Table 6. P-value for Whale and whale-watching management at Bahía de Banderas

\begin{tabular}{|c|c|c|c|c|c|c|}
\hline & $\begin{array}{l}\text { their trip } \\
\text { should } \\
\text { ensure } \\
\text { whale } \\
\text { watching }\end{array}$ & $\begin{array}{l}\text { the number } \\
\text { of whale } \\
\text { watching } \\
\text { boats } \\
\text { around the } \\
\text { whales } \\
\text { should be } \\
\text { limited }\end{array}$ & $\begin{array}{l}\text { there should } \\
\text { be some } \\
\text { reserved } \\
\text { areas where } \\
\text { whale } \\
\text { watching is } \\
\text { not } \\
\text { permitted }\end{array}$ & $\begin{array}{l}\text { whale } \\
\text { populations } \\
\text { are in } \\
\text { danger }\end{array}$ & $\begin{array}{l}\text { part of the costs } \\
\text { of whale } \\
\text { watching should } \\
\text { go directly to } \\
\text { research } \\
\text { projects and } \\
\text { management of } \\
\text { whale }\end{array}$ & $\begin{array}{l}\text { keeping } \\
\text { whales in } \\
\text { aquariums }\end{array}$ \\
\hline $\begin{array}{l}\text { U de Mann- } \\
\text { Whitney }\end{array}$ & 11758.500 & 9983.500 & 11309.500 & 11123.000 & 9799.000 & 10887.500 \\
\hline $\begin{array}{l}\text { W de } \\
\text { Wilcoxon }\end{array}$ & 16909.500 & 15033.500 & 16259.500 & 39089.000 & 14849.000 & 37222.500 \\
\hline Z & -.202 & -2.386 & -.243 & -.903 & -2.606 & -.763 \\
\hline $\begin{array}{l}\text { Sig. asintot. } \\
\text { (bilateral) }\end{array}$ & .840 & .017 & .808 & .367 & .009 & .445 \\
\hline
\end{tabular}

a. Grouping variable: Company 


\section{DISCUSSION}

Our results in this study show that while expectations and opinions regarding whale watching management of respondents that choose to go whale watching on private (PC) versus community-based Cooperativa (CC) vessels are generally similar, the demographics and satisfaction are different. Private companies are chosen more often than the Cooperativa by foreign tourists. This result can likely be explained by PC advertising in hotels and popular tourist areas, such as the Malecon; PC whale watching trips can also be booked on PC websites or in conjunction with hotel reservations before foreign tourists arrive in Puerto Vallarta. Although it is cheaper to go whale watching with the Cooperativa, they do very little advertising and Punta de Mita is a 30-minute drive from Puerto Vallarta. The majority of visitors that choose the Cooperativa are Mexicans who likely find out about the CC by word-of-mouth. The Cooperativa also seems to receive repeat visitors, indicated by the facts that a greater percentage of whale watchers that chose the $\mathrm{CC}$ had been whale watching previously, but not many had gone whale watching in other countries.

The two groups appear to have learned about whales from different sources: TV is the most popular media used by PC whale watchers, while the internet and magazines are more popular with CC whale watchers. Given the country of origin differences, this may be related to cultural learning differences or differential access to various types of media. This difference did not seem to translate into different expectations for the whale watching trip or opinions about whale watching management, however.

In fact, there were no significant differences in expectations between $\mathrm{PC}$ and $\mathrm{CC}$ whale watchers regarding expectations for either the experiential or learning items. For whale watchers on both platforms it was most important to "See whales in a manner that is respectful to the whales and their environment", followed by "See a whale even if it only one." "See whales up close to the boat" was also important to both groups, however, which is counter to results found by Orams [32] and seemingly in opposition to "See whales in a manner that is respectful to the whales and their environment." Our results are more similar to Kessler, Harcourt and Bradford [33] who found that whale watchers reported a desire to be closer to whales, even when they understood the minimum distance restrictions. These results are reflective of Curtain [34] who found that close encounters in wildlife viewing are important to the participants. Learning items were generally less important than experiential items to participants on both the PC and CC vessels. This result is discussed in more depth by Malcolm, Chavez-Dagostino and Cornejo-Ortega [30], where we suggest, following Beaumont [35], Uysal et al. [36], and Malcolm and Duffus [37] that ecotourists lacking special skills or experience is correlated with less interest in the environment. It is interesting to note that all in cases of the learning expectation items the $\mathrm{CC}$ whale watchers, who had a higher incidence of previous whale watching, exhibited higher means, although the scores are not statistically significant. It would be interesting to explore further whether increased instances of whale watching result in different learning expectations perhaps with a larger sample size.

Unlike the expectation means, the satisfaction means revealed some significant differences between the two group types. For 12 of the 14 items passengers aboard PC vessels reported significantly higher satisfaction than those aboard CC vessels. Additionally, in all cases PC satisfactions were higher than their expectations for the same items, indicating a highly satisfied group. With respect to CC satisfaction, seven of the 14 items fell above the isoline in Fig. 4, indicating a lower satisfaction than expectation for these items. These results included both experiential ("See ...") and learning items so the dissatisfaction was not restricted to either what they saw or what they learned. Malcolm and Duffus [37] stated 
that increased experience whale watching would provide previous context and might lead to more realistic expectations and consequently increased satisfactions; however, this did not occur in this case as the $\mathrm{CC}$ whale watchers reported more prior experience than the PC whale watchers. It is possible that the $\mathrm{CC}$ dissatisfaction might be linked to the presence of professional staff with biological backgrounds as guides aboard the PC vessels that are able to give a comprehensive explanation of the activity, while the $\mathrm{CC}$ do not usually have biologically trained staff and the boat captain may or may not converse with the passengers. Environmental education is essential for sustainable ecotourism. Providing educational information about cetaceans and marine life to whale/dolphin watching tourists has been reported to encourage positive responses from passengers (e.g., better acceptance and improved appreciation for implementation of guidelines, increased awareness for cetaceans and marine conservation, improved tourist satisfaction that could lead to repeat visits and recommendations) $[38,39]$. Perhaps education is warranted in this location, as both groups desired to be closer to the whales, which is contrary to results in Lovina, Indonesia, where passengers were dissatisfied with the vessel captains' driving behavior [40]. Given that the excessive number of boats and extreme proximity to the dolphins is likely to lead to behavioral changes [41-43]. Nevertheless this results support investigations about dolphin watching. All respondents on this survey had seen dolphins on their trip, which logically contributed towards their positive experience and "fantastic" or "good" responses. Similar responses were reported in studies in other whale/dolphin watch locations where interviews were conducted with tourists, all or most of whom succeeded in seeing cetaceans on trips off the coasts of California [44], Tangalooma, Australia [32], the Great Barrier Reef [45], San Juan Islands, Washington [46], and Newfoundland, Canada [47].

There were no significant differences between tourists on PC versus $\mathrm{CC}$ vessels with respect to whale and whale watching management. For example, nearly $80 \%$ of visitors on both vessel types agreed that there should be reserved areas where whale watching is restricted. In fact, whale watching vessels are prohibited in Marietas Islands Ecological Reserve, located near whale watching activities in northern Bahía de Banderas, but whale watching naturalists rarely mention this. Naturalists do often mention that humpback whales are nowlisted as "Least Concern" on the IUCN Red List of Threatened Species and that attitudes towards conservation of cetaceans, such as those found in this study, are important for sustainability of the species and whale watching in the future.

\section{CONCLUSIONS}

Whether respondents in this study choose to participate in whale watching on a private company (PC) or community-based Cooperativa (CC) vessel did not result in any expectation differences for the trip, even though there were country of origin and previous experience differences between the groups. However, there were differences in satisfaction following the trip. Whether this was due to on board interpretation, how the vessel was driven near whales, or something else, we do not know. If the satisfaction is lower, why do the $\mathrm{CC}$ vessels receive repeat customers? This could be examined with further research. We suggest, however, that the Cooperativa explore how to incorporate more interpretation during their trips. It would also be interesting to explore whale watching experiences with community-based whale watching ventures in other locations. Similarly, it would be beneficial to conduct a comprehensive study in various locations on the desire of whale watchers to get close to whales, due to the variability in the literature, to explore whether the differences are geographical, 
cultural, or educational In the end, whale watch operators in the area should be aware that the most important expectation and highest satisfaction for passengers on both company types was "to see whales in a respectful manner," which offers an opportunity for all operators in the Bahía de Banderas to ensure best practices are followed for both continued satisfaction of their passengers and conservation of local whale populations.

\section{REFERENCES}

[1] SECTUR Elementos para evaluar el impacto económico, social y ambiental del turismo de naturaleza en México, Secretaría de Turismo, México, 158p. 2007.

[2] Brown, D.F., Mayas and tourists in the maya world. Human Organization, 58(3), pp. 295-304, 1999.

https://doi.org/10.17730/humo.58.3.y21r558615941121

[3] Daltabuit, M., Cisneros, H., Vázquez, L.M. \& Santillán, E., Ecoturismo y desarrollo sustentable. Impacto en comunidades rurales de la selva maya, UNAM-CRIM, México, 2000.

[4] Honey, M., Treading lightly? Ecotourism's impact on the environment. Environment, 41(5), pp. 4-12, 1999, available at http://www.conanp.gob.mx/pdf_especies/PACE-BJOROBADA-1.pdf (accessed 5 June 2015) https://doi.org/10.1080/00139159909604631

[5] Beeton, S., Community Development Through Tourism, Landlinks Press, Collingwood (Australia), 2006.

[6] Rocharungsat, P., Community-based tourism in Asia. Building Community Capacity for Tourism Development, ed. G. Moscardo, CABI Publishing: Cambridge, MA, pp. 60-74, 2008.

[7] Brandon, K., Ecotourism and Conservation: A review of Key Issues. Environment Department Working Papers, No. 033. Environmentally and Socially Sustainable Development. Biodiversity series. Washington, DC: World Bank, 1996, available at http:// documents.worldbank.org/curated/en/101351468767955325/Ecotourism-and-conservation-a-review-of-key-issues (accesed 20 Septeber 2017).

[8] Bookbinder, M.P., Eric, D., Arun, R., Hank, C. \& Arup, R., Ecotourism's support of biodiversity. Conservation Biology, 12(6), pp. 1399-1404, 1998. https://doi.org/10.1111/j.1523-1739.1998.97229.x

[9] Perhaps Zeppel, H. \& Muloin, S., Green messengers or nature's spectacle: understanding visitor experiences of wild cetacean tours. Whale-watching: Sustainable Tourism and Ecological Management, eds. J. Higham, L. Bejder \& R. Williams, Cambridge University Press: New York, pp. 110-127, 2014.

[10] Parsons, E., The negative impacts of whale-watching. Journal of Marine Biology, 2012, pp. 1-9, 2012.

https://doi.org/10.1155/2012/807294

[11] Higham, J.E.S., Bejder, L., Allen, S.J., Corkeron, P.J. \& Lusseau, D., Managing whalewatching as a non-lethal consumptive activity. Journal of Sustainable Tourism, 24(1), pp. 73-90, 2016.

[12] O'Connor, S., Campbell, R., Cortez, H. \& Knowles, T., Whale Watching Worldwide: tourism numbers, expenditures and expanding economic benefits, a special report from the International Fund for Animal Welfare, Yarmouth MA, USA, prepared by Economists at Large. 2009. 
[13] Cisneros-Montemayor, A.M., Sumaila, U.R., Kaschner, K. \& Pauly, D., The global potential for whale watching. Marine Policy, 34, pp. 1273-1278, 2010.

https://doi.org/10.1016/j.marpol.2010.05.005

[14] Draheim, M., Bonnelly, I., Bloom, T., Rose, N. \& Parsons, E.C.M., Tourist attitudes towards marine mammal tourism: an example from the Dominican Republic. Tourism in Marine Environments, 6(4), pp. 175-183, 2010.

https://doi.org/10.3727/154427310x12764412619046

[15] Mustika, P.L.K., Birtles, A., Everingham, Y. \& Marsh, H., The human dimensions of wildlife tourism in a developing country: Watching spinner dolphins at Lovina, Bali, Indonesia. Journal of Sustainable Tourism, 21, pp. 229-251, 2013. https://doi.org/10.1080/09669582.2012.692881

[16] Cornejo-Ortega, J.L. \& Chávez-Dagostino, R.M., La huella de carbono de la observación de ballena jorobada (Megaptera novaeangliae) en las islas Marietas, Nayarit, México. Revista Internacional de Contaminación Ambiental, 30(1), pp. 121-130, 2014.

[17] Parsons, E.C.M., Warburton, C., Woods-Ballard, A., Hughes, A., Johnston, P., Bates, H. \& Luck, M., Whale-watching tourists in West Scotland. Journal of Ecotourism, 2(2), pp. 93-113. 2003.

https://doi.org/10.1080/14724040308668137

[18] Moyle, P.B. \& Cech, J.J., Fishes an Introduction to Ichthyology. Prentice Hall, Englewood Cliffs, New Jersey, 559p. 1998.

[19] Briggs, J.C., Marine Zoogeography. McGraw-Hill, New York, 475p, 1974.

[20] Wyrtki, K., Surfice currents in the eastern Equatorial Pacific Ocean. Inter-American Tropical Tuna Commission Bulletin, (9), pp. 270-304, 1965.

[21] Chávez, R. \& De la Cueva, H., Sustentabilidad y regulación de la observación de ballenas en México. Revista Legislativa de Estudios Sociales y de Opinión Pública, 2(4), pp. 231-262, 2009.

[22] CONANP, Número de visitantes y permisos otorgados en el PNIM. Oficio DROP/ PNIMT/006/2016, Dirección Regional Occidente y Pacífico Centro. Puerto Vallarta, Jalisco 2015

[23] SEMARNAT Solicitudes e informes para aprovechamiento no extractivo (observación de ballenas). Informe del MVZ Francisco Rafael Zermeño Núñez, Temporada 20142015, Puerto Vallarta Jalisco. 2014.

[24] Rodríguez, V., Potencial turístico e impacto de la observación de ballena jorobada (Megaptera novaeangliae) en Bahía de Banderas, México. Guadalajara: Centro Universitario de Ciencias Biológicas y Agropecuarias, Universidad de Guadalajara, 2000.

[25] Beets, K.D., Observaciones de ballenas en la Bahía de Banderas como actividad turística sustentable. Puerto Vallarta: Centro Universitario de la Costa, Universidad de Guadalajara, Tesis de Maestría, 88p, 2006.

[26] Cornejo-Ortega, J.L., Chávez-Dagostino, R.M. \& Massam, B., Sustainable tourism: whale watching footprint in the Bahía de Banderas, México. Journal of Coastal Research, 29(9), pp. 1445-1451, 2013.

https://doi.org/10.2112/jcoastres-d-12-00213.1

[27] Cornejo-Ortega, J.L. \& Chávez-Dagostino, R.M., Implicaciones en la observación de la ballena jorobada. Temas sobre investigaciones costeras, ed. J. Cifuentes \& F. Cupul, Universidad de Guadalajara, México, pp. 143-171, 2014. 
[28] Avila-Foucat, V.S., Sánchez-Vargas, A., Frish-Jordan, A. \& Ramírez-Flores, O.M., The impact of vessel crowding on the probability of tourists returning to whale watching in Banderas Bay, Mexico. Ocean and Coastal Management, 78(2013), pp. 12-17, 2013. https://doi.org/10.1016/j.ocecoaman.2013.03.002

[29] Cornejo-Ortega, J.L.; Chávez-Dagostino, R.M. \& Ivanova-Boncheva, A., Climate change and whale watching: tourists perception in Islas Marietas, Nayarit, México. International Journal of Sustainable Development and Planning, 9(4), pp. 553-567, 2014. https://doi.org/10.2495/sdp-v9-n4-553-567

[30] Malcolm, C., Chávez-Dagostino, R.M. \& Cornejo-Ortega, J.L., Experiential and learning desires of whale watching guides versus tourists in Bahía de Banderas, Puerto Vallarta, México. Human Dimensions of Wildlife, 22(6), pp. 524-537, 2017. https://doi.org/10.1080/10871209.2017.1367442

[31] Cochran, W.G., Sampling Techiniques (3rd ed.). USA: John Wiley \& Sons, Inc. p. 75, 1977.

[32] Orams, M.B., Tourists getting close to whales, is it what whale-watching is all about? Tourism Manage ment, 21(6), pp. 561-569, 2000. https://doi.org/10.1016/s0261-5177(00)00006-6

[33] Kessler, M., Harcourt, R. \& Bradford, W., Will whale watchers sacrifice personal experience to minimize harm to whales? Tourism in Marine Environments, 10(1), pp. 21-30, 2014. https://doi.org/10.3727/154427314x14056884441662

[34] Curtin, S., The self-presentation and self-development of serious wildlife tourists. International Journal of Tourism Research, 12, pp. 17-33, 2010. https://doi.org/10.1002/jtr.734

[35] Beaumont, N., Ecotourism and the conservation ethic: recruiting the uninitiated or preaching to the converted? Journal of Sustainable Tourism, 9(4), pp. 317-341, 2001. https://doi.org/10.1080/09669580108667405

[36] Uysal, M., Jurowski, C., Noe, F.P. \& McDonald, C.D. Environmental attitude by trip and visitor characteristics. Tourism Management, 15, pp. 284-294, 1994. https://doi.org/10.1016/0261-5177(94)90046-9

[37] Malcolm, C.D. \& Duffus, D.A., Specialization of whale watchers in British Columbia waters. Marine Wildlife and Tourism Management, eds. J.E. Higham \& M. Lück, CABI Publishing: London, pp. 109-129, 2008.

[38] Ballantyne, R., Packer, J. \& Hughes, K., Tourists' support for conservation messages and sustainable management practices in wildlife tourism experiences. Tourism Management, 30, pp. 658-664, 2009. https://doi.org/10.1016/j.tourman.2008.11.003

[39] Garrison, B., The nature and adventure traveler: tourism growth potential in Clearwater Beach. Unpublished report, Dolphin-Aware Pilot Project, Initial Meeting of Local Stakeholders, Clearwater, Florida, 2003.

[40] Mustika, P.L.K., Birtles, A., Welters, R. \& Marsh, H., The economic influence of community-based dolphin watching on a local economy in a developing country: implications for conservation. Ecological Economics, 79, pp. 11-20, 2012. https://doi.org/10.1016/j.ecolecon.2012.04.018 
[41] Constantine, R., Brunton, D.H. \& Dennis, T., Dolphin-watching tour boats change bottlenose dolphin (Tursiops truncatus) behaviour. Biological Conservation, 117, pp. 299-307, 2004. https://doi.org/10.1016/j.biocon.2003.12.009

[42] Stensland, E. \& Berggren, P., Behavioural changes in female Indo-Pacific bottlenose dolphins in response to boat-based tourism. Marine Ecology Progress Series, 332, pp. 225-234, 2007. https://doi.org/10.3354/meps332225

[43] Christiansen, F., Lusseau, D., Stensland, E. \& Berggren, P., Effects of tourist boats on the behaviour of Indo-Pacific bottlenose dolphins off the south coast of Zanzibar. Endangered Species Research, 11, pp. 91-99, 2010. https://doi.org/10.3354/esr00265

[44] Tilt, W.C., From whaling to whale-watching. Transactions of the North American Wildlife and Natural Resources Conference, 52, pp. 567-585, 1987.

[45] Birtles, A., Valentine, P., Curnock, M., Arnold, P. \& Dunstan, A., Incorporating visitor experiences into ecologically sustainable Dwarf Minke whale tourism in the northern Great Barrier Reef (CRC Reef Research Centre Technical Report No. 42). Townsville: CRC Reef Research Centre Ltd. 2002.

[46] Andersen, M.S. \& Miller, M.L., Onboard marine environmental education: Whalewatching in the San Juan Islands, Washington. Tourism in Marine Environments, 2(2), pp. 111-118, 2006.

https://doi.org/10.3727/154427306779436327

[47] Corbelli, C., An evaluation of the impact of commercial whale-watching on humpback whales, Megaptera novaeangliae, in Newfoundland and Labrador, and of the effectiveness of a voluntary code of conduct as a management strategy. Ph.D. thesis, Memorial University, Newfoundland, 2006. 